\title{
Profil Trauma Tembus pada Mata di RSUP Prof. Dr. R.D. Kandou Manado Periode Januari 2016 - Juli 2018
}

\author{
${ }^{1}$ Imanuel H. Pantow \\ ${ }^{2}$ Vera Sumual \\ ${ }^{2}$ Rillya D. P. Manoppo
}

\author{
${ }^{1}$ Program Studi Pendidikan Dokter Fakultas Kedokteran Universitas Sam Ratulangi Manado \\ ${ }^{2}$ Bagian Ilmu Kesehatan Mata Fakultas Kedokteran Universitas Sam Ratulangi Manado \\ E-mail: imanuelpantow74@gmail.com
}

\begin{abstract}
Although eye trauma cases are oftenly found, they are actually preventable. The incidence of open eye trauma is around 3.6-3.8 in 100,000 people worldwide. This study was aimed to obtain the profile of penetrating trauma in the eye at Prof. Dr. R. D. Kandou Hospital Manado. This was a retrospective analytical study using medical record data of Prof. Dr. R. D. Kandou Hospital from January 2016 to July 2018. The results showed 124 patients with penetrating trauma in the eye. Penetrating trauma cases in the eyes were significantly higher in males compared to females which were found in 105 patients (87.67\%). Based on age, most patients were in the early adult age category (26-35 years) as many as 28 patients $(22.58 \%)$. Based on work, the most common patients were farmers as many as 25 patients $(20.16 \%)$, followed by laborers as many as 18 patients $(14.51 \%)$. Conclusion: Most cases of penetrating trauma in the eyes were males, aged 26-35 years, and worked as farmers.
\end{abstract}

Keywords: incidence, penetrating eye trauma

\begin{abstract}
Abstrak: Trauma pada mata sering terjadi dan sebenarnya merupakan penyebab gangguan penglihatan yang dapat dicegah. Insidensi trauma mata terbuka sekitar 3.6-3.8 per 100.000 populasi di seluruh dunia. Penelitian ini bertujuan untuk mendapatkan gambaran kejadian trauma tembus pada mata di RSUP Prof.DR.R.D Kandou Manado. Jenis penelitian ialah analitik retrospektif dengan menggunakan data di Bagian Rekam Medik RSUP Prof. Dr. R. D. Kandou Manado periode Januari 2016-Juli 2018. Hasil penelitian mendapatkan jumlah pasien trauma tembus pada mata sebanyak 124 orang. Kasus trauma tembus pada mata lebih banyak terjadi pada laki-laki dibandingkan perempuan yaitu 105 pasien $(87,67 \%)$. Berdasarkan usia, trauma tembus pada mata terbanyak pada kategori dewasa awal (26-35 tahun) sebanyak 28 pasien $(22,58 \%)$. Berdasarkan pekerjaan, trauma tembus pada mata terbanyak didapatkan pada petani sebanyak 25 pasien $(20,16 \%)$ diikuti buruh sebanyak 18 pasien $(14.51 \%)$. Simpulan: Trauma tembus pada mata terbanyak pada laki-laki, usia 26-35 tahun, didominasi pekerjaan sebagai petani.
\end{abstract}

Kata kunci: angka kejadian, trauma tembus pada mata

Mata merupakan salah satu dari lima indera yang digunakan manusia untuk mengenal dunia sekitarnya. Dengan menggunakan mata, manusia dapat memperoleh informasi, sebanyak $80 \%$ hanya dengan melihat. ${ }^{1}$ Trauma pada mata sering terjadi dan sebenarnya merupakan penyebab gangguan penglihatan yang dapat dicegah. Angka kejadian trauma pada mata mencapai 19,8\% secara keseluruhan mulai dari abrasi epitel kornea yang kecil sampai trauma tembus yang lebih berat serta trauma yang menyebabkan ruptur pada mata. ${ }^{2}$

Pada kelompok usia anak angka kejadian trauma pada mata mencapai 8$14 \%$ dan biasanya terjadi karena kasus 
kecelakaan dan mengenai salah satu mata saja. Sebaliknya, pada orang dewasa sering terjadi akibat kelalaian atau kesengajaan dengan maksud mencelakai seseorang. Laki-laki lebih sering mengalami hal ini dibandingkan dengan perempuan, kira-kira 4:1 dan paling sering pada kelompok usia dewasa muda. Pasien dengan riwayat trauma okular, tiga kali lebih berisiko rekurensi dalam periode lima tahun dibandingkan dengan mereka yang tidak pernah mengalami cedera sebelumnya. ${ }^{2}$

Insidensi trauma mata terbuka sekitar 3.6-3.8 per 100.000 populasi di seluruh dunia. Trauma mata terbuka dapat diklasifikasikan menjadi laserasi dan ruptur akibat trauma bergantung pada mekanismenya. Pada laserasi, jika terdapat celah masuknya benda dan menyebabkan adanya jaringan yang keluar dan terjadi pada satu waktu yang sama dan disebabkan oleh faktor yang sama dikatakan sebagai double penetrating globe injury atau perforasi. Namun apabila hanya satu saja tempat paparan terjadinya luka tanpa adanya bagian mata yang menonjol keluar didefinisikan sebagai penetrating injury. Terdapat dua puncak angka kejadian, yang pertama pada kelompok usia dewasa muda dan lainnya pada kelompok lansia di atas 70 tahun dan lebih banyak terjadi pada laki-laki dibanding dengan perempuan, mungkin dapat dihubungkan dengan kepribadian atau perilaku laki-laki yang memiliki karakteristik lebih agresif. ${ }^{3}$

Secara umum trauma pada mata terbagi atas trauma terbuka dan trauma tertutup. Birmingham Eye Trauma Terminology membuat klasifikasi merujuk pada keseluruhan bagian mata. Yang termasuk dalam trauma mata terbuka yaitu laserasi yang selanjutnya dibagi lagi menjadi trauma tembus, perforasi, dan benda asing intraocular sedangkan yang termasuk dalam trauma mata tertutup yaitu trauma akibat luka bakar, kontusio, trauma tumpul dan laserasi lamelar. ${ }^{4-6}$

\section{METODE PENELITIAN}

Jenis penelitian ini ialah analitik retrospektif dengan menggunakan data di
Bagian Rekam Medik RSUP Prof DR.R.D Kandou Manado periode Januari 2016- Juli 2018.

\section{HASIL DAN BAHASAN}

Hasil penelitian memperlihatkan bahwa pada periode Januari 2016-Juli 2018, terdapat sebanyak 124 pasien yang didiagnosis trauma tembus pada mata di RSUP Prof. Dr. R. D. Kandou Manado dengan kejadian terbanyak di periode JanuariDesember 2017 yaitu 53 kasus (Tabel 1).

Tabel 1. Angka kejadian trauma tembus pada mata di RSUP Prof. Dr. R. D. Kandou Manado periode Januari 2016-Juli 2018 berdasarkan jenis kelamin

\begin{tabular}{ccc}
\hline Jenis kelamin & Jumlah & $\mathbf{( \% )}$ \\
\hline Laki - laki & 105 & 87,67 \\
Perempuan & 19 & 15,32 \\
Total & 124 & 100 \\
\hline
\end{tabular}

Kejadian trauma tembus pada mata berdasarkan jenis kelamin paling banyak pada jenis kelamin laki-laki yaitu 105 pasien $(87,67 \%)$ sedangkan pada jenis kelamin perempuan hanya 19 pasien $(19,52 \%)$ (Tabel 2). Hal ini mungkin disebabkan karena laki-laki lebih sering melakukan aktivitas yang berisiko. Hal ini didukung oleh penelitian yang dilakukan Havens et al. $^{2}$ yang menyatakan bahwa trauma tembus pada mata terutama terjadi pada laki-laki dari pada perempuan dengan perbandingan $4: 1$.

Tabel 2. Angka kejadian trauma tembus pada mata di RSUP Prof.Dr.R.D Kandou Manado periode Januari 2016 - Juli 2018 berdasarkan usia

\begin{tabular}{ccc}
\hline Kategori usia & Jumlah & $\mathbf{( \% )}$ \\
\hline Balita & 4 & 3,22 \\
Kanak-kanak & 13 & 10,48 \\
Remaja awal & 5 & 4,03 \\
Remaja akhir & 16 & 12,90 \\
Dewasa awal & 28 & 22,58 \\
Dewasa akhir & 22 & 17,74 \\
Lansia awal & 18 & 14,51 \\
Lansia akhir & 16 & 12,90 \\
Manula & 2 & 1,61 \\
Total & 124 & 100 \\
\hline
\end{tabular}


Kejadian terbanyak trauma tembus pada mata selama periode Januari 2016-Juli 2018 terjadi pada kategori usia dewasa awal (usia 26-35 tahun) dengan jumlah pasien sebanyak 28 orang $(22,58 \%)$, diikuti kategori usia dewasa akhir (36-45 tahun) sebanyak 22 pasien $(17,74 \%)$, sedangkan yang paling sedikit pada kategori usia manula (>65 tahun) yaitu 2 pasien $(1,61 \%)$. Angka ini sejalan dengan penelitian yang dilakukan Mcgwin dan Owsley $^{7}$ yang menyatakan bahwa puncak kejadian trauma tembus terdapat pada rentang usia 20-30 tahun.

Tabel 3. Angka kejadian trauma tembus pada mata di RSUP Prof. Dr. R. D. Kandou Manado periode Januari 2016-Juli 2018 berdasarkan pekerjaan.

\begin{tabular}{ccc}
\hline Pekerjaan & Jumlah & $\mathbf{( \% )}$ \\
\hline Buruh & 18 & 14,51 \\
IRT & 9 & 7,25 \\
Mahasiswa & 5 & 4,03 \\
Pegawai swasta & 15 & 12,09 \\
Pelajar & 13 & 10,48 \\
Pendeta & 1 & 0,80 \\
Petani & 25 & 20,16 \\
Sopir & 4 & 3,22 \\
PNS & 10 & 8,06 \\
Tukang & 8 & 6,45 \\
TNI / POLRI & 3 & 2,41 \\
Wiraswasta & 3 & 2,41 \\
Dibawah umur & 7 & 5,64 \\
Tidak bekerja & 3 & 2,41 \\
Total & 124 & 100 \\
\hline
\end{tabular}

Jenis pekerjaan merupakan salah satu faktor risiko penting terjadinya trauma tembus pada mata. Pada penelitian ini, angka kejadian trauma tembus pada mata berdasarkan pekerjaan sebagai petani yang tertinggi dengan jumlah 25 pasien $(20,16 \%)$ dari total 124 pasien yang terdiagnosis trauma tembus pada mata selama periode Januari 2016-Juli 2018, diikuti pekerjaan sebagai buruh sebanyak 18 pasien $(14,51 \%)$, pegawai swasta sebanyak 15 pasien $(12,09 \%)$, dan pelajar sebanyak 13 pasien $(10,48 \%)$ sedangkan yang paling sedikit pada pekerjaan sebagai pendeta yaitu hanya 1 pasien $(0,82 \%)$. Pada penelitian ini juga didapatkan sejumlah 3 pasien yang tidak bekerja. Jenis pekerjaan petani dan buruh menjadi yang terbanyak, dapat dihubungkan dengan etiologi dari trauma tembus pada mata yaitu pada pekerja pertanian dan industri.

\section{SIMPULAN}

Berdasarkan hasil penelitian ini dapat disimpulkan bahwa trauma tembus pada mata terbanyak pada laki-laki, usia 26-35 tahun, dengan pekerjaan sebagai petani.

\section{DAFTAR PUSTAKA}

1. Andriono GA. Kecacatan akibat kecelakaan kerja dan penyakit akibat kerja pada mata. 2005 [cited 2018 August 2] Avaible from: http: //www.jamsostek. co.id /content_file/ mata.pdf.

2. Havens S, Kosoko-Lasaki $\mathbf{O}$, Millicent $P$. Penetrating eye injury: a case study. Am J Clin Med. 2009;6(1):42-8.

3. Hung KH, Yang CS, et al. Management of double penetrating ocular injury with retained intraorbital metallic foreign body. J Chin Med Assoc. 2011; 74(11):523-6.

4. Sukati VN. Ocular injuries - a review. The South African Optometrist. 2012;71 (2):86-9.

5. Larque DAB, Paralta CJ, Lopez AJ. Epidemiology of open globe trauma in the Southeast of Spain. Eur J Opthamol. 2010;20(3):578-82.

6. Potockova A, Strmen P, Krasnik V, Olah Z. Mechanical injuries of the eye. Bratisl Lek Listy. 2010:111(6):329-33.

7. McGwin G Jr, Owsley C. Incidence of Emergency Department-Treated Eye Injury in the United States. Arch Ophthalmol. 2005;123(5):662-6. 